\title{
Response of Seed Collection from Different Parts on the Growth and Yield of Lentil
}

\author{
A. Khatun ${ }^{\mathrm{a} *}$, M. A. H. Bhuiyan ${ }^{\mathrm{b}}$ and M. S. Alam ${ }^{\mathrm{a}}$ \\ ${ }^{a}$ Planning and Evaluation Division, Bangladesh Agricultural Research Institute, \\ Joydebpur, Gazipur-1701, ${ }^{b}$ Soil Science Division, Bangladesh Agricultural \\ Research Institute, Joydebpur, Gazipur-1701,
}

\begin{abstract}
Field experiments were carried out to determine the effects of seeds collected from different parts on growth, yield and yield attributes of lentil. Lentil seeds of three varieties (BARI Masur-2, BARI Masur-3 and BARI Masur-4) were collected from different parts i.e. P1: collection of pods from upper parts of lentil plants, P2: collection of pods from middle parts of lentil plants, P3: collection of pods from lower parts of lentil plants prior to harvesting. All the seeds were stored in earthen pot until conducting the laboratory study. Non-significant variation was observed in three varieties of lentil for most of the parameters studied. The highest plant height, pods plant ${ }^{-1}$, seeds pod ${ }^{-1}$, 1000 seed weight and seed yield were observed in BARI Masur-4 and the lowest in BARI Masur-2. Seeds collected from middle parts of lentil recorded the highest pods plant ${ }^{-1}$, seeds pod ${ }^{-1}$ and seed yield (804 kg ha ${ }^{-1}$ in 2004-05 and $838 \mathrm{~kg} \mathrm{ha}^{-1}$ in 2005-06). BARI Masur-3 seeds were collected from middle parts and BARI Masur-4 from lower parts recorded higher seed yield (1003 kg ha ${ }^{-1}$ in $2004-05$ and $1012 \mathrm{~kg}^{-1} \mathrm{in}^{-1}$ 2005-06 for BARI Masur-3 x P2, $1061 \mathrm{~kg} \mathrm{ha}^{-1}$ in 2004-05 and $856 \mathrm{~kg} \mathrm{ha}^{-1}$ in 2005-06 for BARI Masur-4 x P3).
\end{abstract}

Key words: Lentil, Seed collection, Variety, Seed yield.

\section{Introduction}

Lentil (Lens culinaris L.) occupies the top most position in terms of popularity and is placed second in terms of area and production in Bangladesh (BBS, 2006). The crop is cultivated during rabi season under rainfed situation. About 80 percent of total lentil produced in the country is grown in Faridpur, Kustia, Jessore, Rajshahi and Pabna districts. The yield of lentil is low in Bangladesh. Bangladesh Agricultural Research Institute has developed a good number of lentil varieties. At present, BARI varieties of lentil are being expanded and becoming popular in the country. Response of these varieties, especially the newly released ones to seed collection from different parts respect of yield has yet to be studied.

BARI Masur-2, BARI Masur-3 and BARI Masur-4 was released in 1993, 1996 and 1996, respectively for stable and high yield with combined resistant to rust and stemphylium blight. BARI Masur-2 was developed through single plant selection from a cross ILL 4353 (India) x ILL 353 (Mexico) made at ICARDA. BARI Masur-3 was developed through single plant selection from a cross BLL 79666 (India) $\mathrm{x}$ Pabna local made at PRC. BARI Masur-4 was developed from the cross ILL 7888 x ILL 5782 made at ICARDA, Syria specifically for Bangladesh. BARI Masur-2, BARI Masur-3 and BARI Masur-4 are semi erect and medium statures cultivar produce a mean yield of $1800 \mathrm{~kg} \mathrm{ha}^{-1}, 2000 \mathrm{~kg} \mathrm{ha}^{-1}$ and $2300 \mathrm{~kg} \mathrm{ha}^{-1}$ with mean plant height of $40-42 \mathrm{~cm}, 42-44 \mathrm{~cm}$

\footnotetext{
* Corresponding author: E-mail: mushtaqurr@yahoo.com
}

and 42-44 cm, respectively. BARI Masur-2, BARI Masur-3 and BARI Masur-4 has a mean 1000-seed weight of $12.5 \mathrm{~g}$, $23.8 \mathrm{~g}$ and $19.8 \mathrm{~g}$, respectively compared to $11.5 \mathrm{~g}$ or less for the local cultivars. BARI Masur-2 matures in 105-110 days, BARI Masur-3 matures in 100-105 days and BARI Masur-4 matures in 110-115 days. Seeds of BARI Masur-2 contain 28.31\% protein and $46.15 \%$ carbohydrates, BARI Masur-3 contain $25.5 \%$ protein and $59.6 \%$ carbohydrate and BARI Masur-4 contain $25.8 \%$ protein and 59.8\% carbohydrate (Afzal et al., 1999).

Seed maturation refers to the morphological, physiological and functional changes that occur from the time of fertilization until the matured ovules are ready for harvest (Delouche, 1973). Seed development is the period between fertilization and maximum fresh weight accumulation and seed maturation begins at the end of seed development and continue up to harvest (Abdul-Baki and Baker, 1973). Physiological maturity is attained when the seed reaches its maximum dry weight (Harrington, 1972) at which nutrients are not flowing into the seed from the mother plant. Seed development and maturation study is important because the seeds may be harvested to ensure good yield associated with viability, vigour and field performance (Dharmalingam and Basu, 1990). Physiological changes might set in, if the seed are retained on the mother plant for longer duration after physiological maturity (Ovcharov and Kizilova, 1966) 
which would lead to the development of hard seeds or offcolour seeds in pulse crops (Dharmalingam and Ramakrishnan, 1978). Seed yield and quality largely depends on the stage of maturity (Kumar et al., 2002). As such, harvesting of seeds at right stage of maturity is most important since harvesting either at early or late stage results in lower yields with poor quality seeds (Khatun et al., 2009).

Seeds collected from different parts of a crop for seed quality depends on their maturity, seed size, vigour etc. Harvesting of seeds from optimum parts of the plant helps to obtain better quality seeds. Seeds collected from different parts influence the quality of the seeds in relation to their germination, vigour, viability and also storability (Khatun et al., 2008). Seed quality in storage is also influenced by the condition, which has not yet been studied for lentil seed storage. Therefore, it is necessary to identify right site for harvesting pulse crops in order to ensure seed quality. So, the experiment was conducted to determine the effects of seeds collected from different parts of lentil to get maximum seed yield.

\section{Materials and Methods}

Experiments were carried out at the Research Field of the Pulse Research Centre, Bangladesh Agricultural Research Institute (BARI), Joydebpur, Gazipur, Bangladesh during the period from Rabi season of 2004-05 and 2005-06. The experiment was conducted to determine the effects of seeds collected from different parts of lentil. Lentil seeds of three varieties viz. BARI Masur-2 $\left(\mathrm{V}_{1}\right)$, BARI Masur-3 $\left(\mathrm{V}_{2}\right)$ and BARI Masur-4 $\left(\mathrm{V}_{3}\right)$ were collected from the Pulses Research Centre experimental field in Rabi seasons of 2003-2004 considering three different parts i.e. $\mathrm{P}_{1}$ : collection of pods from upper parts of lentil plants, $\mathrm{P}_{2}$ : collection of pods from middle parts of lentil plants, $\mathrm{P}_{3}$ : collection of pods from lower parts of lentil plants prior to harvesting. All the seeds were stored in earthen pot until conducting the laboratory study. The collected seeds were preserved in the earthen pot. Before setting up the field experiment, laboratory experiment was carried out for recording the seed quality data (moisture percentage, germination percentage, vigour etc.). The experimental field was well drained high land with moderately even topography having irrigation facilities. The area belongs to the Agro-ecological Zone (AEZ 28) under Madhupur Tract. The experimental site is situated at $24.00^{\circ}$ North Latitude and $90.26^{\circ}$ East Longitude.

Field experiments were conducted with the above seeds. The experiments were conducted in a factorial randomized complete block design. The row to row spacing was $30 \mathrm{~cm}$ and plant to plant $10 \mathrm{~cm}$. The unit plot size was $3 \mathrm{~m} \mathrm{x} 4 \mathrm{~m}$. Seeds were sown on 18 November 2004 and 11 November 2005 and harvested on 01 March 2005 and 25 February 2006.
Among the ten rows of each plot, middle 6 rows were kept for harvesting per plot seed yield. Outer two rows except the border rows from each side were used for sampling of plant height. After harvesting, 10 plants from each plot excluding border lines were selected randomly and tagged by a sample stick to record necessary data. The sample plants were uprooted carefully from the soil.

The following growth, yield and yield-contributing characters were recorded:

\section{Plant height}

The data on plant height were recorded by taking 5 randomly selected plants from each plot at different days after sowing (DAS) (i.e. 20 days interval). The data on plant height were expressed in $\mathrm{cm}$.

\section{Days to 1st flowering}

Days to 1st flowering was counted from the date of sowing to the date of 1st flowered in each plot.

\section{Days to $\mathbf{5 0} \%$ flowering}

Days to $50 \%$ flowering was counted from the date of sowing to the date of $50 \%$ of plants flowered in each plot.

\section{Days to maturity}

Days required from the date of sowing to maturity of a plant were recorded.

\section{Pods plant ${ }^{-1}$}

Total number of pods was counted from ten selected plants separately.

\section{Seeds pod ${ }^{-1}$}

Ten pods were selected randomly from the bulk of the pods harvested from ten selected plants and numbers of seeds are counted individually from each of them.

\section{0-seed weight}

For seed weight, 1000-seeds were counted and their dry weight was taken.

\section{Seed yield}

Yield data were collected from $3 \mathrm{~m}$ x $1.8 \mathrm{~m}$ area of each plot and the yields were converted to $\mathrm{kg} \mathrm{ha}^{-1}$. Lentil crops wereharvested on 01 March 2005 in first year and on 25 February 2006 in second year. The harvested seeds were threshed, cleaned, and dried properly. Data on yield and yield components i.e. seed yield $\left(\mathrm{kg} \mathrm{ha}^{-1}\right)$, pods plant ${ }^{-1}$, seeds pod $^{-1}$, 1000 -seed weight was recorded. Each seed sample was then divided into three and stored in earthen pot for next growing season. 


\section{Statistical analysis}

The data for different characters were compiled and tabulated in proper form and then subjected to statistical analysis following a computer IRRISTAT package programme adjusted the means. The correlation co-efficient and regression analysis were done for different variables wherever needed.

\section{Results and Discussion}

\section{Plant height}

Plant height of different varieties varied significantly only at 1st sampling in 2005-06 (Table I). BARI Masur-3 had the highest plant height of $37.2 \mathrm{~cm}$ in 2004-05 and $39.1 \mathrm{~cm}$ in 2005-06 in BARI Masur-4 on last sampling (26-02-2005 and 19-02-2006). The lowest plant height (5.5 cm in 2004-05 and

\section{Table I. Effects of varieties of lentil on plant height}

$38.3 \mathrm{~cm}$ was observed in $\mathrm{V}_{3} \times \mathrm{P}_{3}$ in 2004-05 and $40.9 \mathrm{~cm}$ in $\mathrm{V}_{3} \times \mathrm{P}_{2}$ in 2005-06.

\section{Days to 1st flowering}

Influence of varieties on days to 1st flowering was non-significant (Table IV). First flowering ranged from 56 to 58 days over varieties and years. Seeds collected from different parts of lentil plants did not influence the 1st flowering (Table V). Interaction effects between varieties and seeds collected from different parts were also non-significant (Table VI). It indicates that all the varieties gave similar response to 1 st flowering.

\section{Days to $\mathbf{5 0} \%$ flowering}

Influence of varieties and seeds collected from different parts and their interaction effect on days to $50 \%$ flowering was non-significant (Tables IV-VI). Bhingarde and Dumbre

\begin{tabular}{|c|c|c|c|c|c|c|c|c|c|c|}
\hline \multirow[t]{3}{*}{ Varieties } & \multicolumn{10}{|c|}{ Plant height $(\mathrm{cm})$} \\
\hline & \multicolumn{5}{|c|}{ 2004-05 } & \multicolumn{5}{|c|}{ 2005-06 } \\
\hline & 20 DAS & 40 DAS & 60 DAS & 80 DAS & 100 DAS & 20 DAS & 40 DAS & 60 DAS & 80 DAS & 100 DAS \\
\hline $\begin{array}{l}\text { BARI } \\
\text { Masur-2 }\end{array}$ & 5.5 & 13.8 & 23.0 & 25.6 & 35.3 & $5.2 b$ & 14.0 & 21.4 & 28.3 & 37.4 \\
\hline $\begin{array}{l}\text { BARI } \\
\text { Masur-3 }\end{array}$ & 5.6 & 14.0 & 22.7 & 25.9 & 35.4 & $5.6 a b$ & 14.6 & 22.5 & 29.0 & 38.3 \\
\hline $\begin{array}{l}\text { BARI } \\
\text { Masur-4 }\end{array}$ & 6.0 & 14.9 & 23.5 & 26.2 & 37.2 & $6.1 \mathrm{a}$ & 14.9 & 24.0 & 29.9 & 39.1 \\
\hline $\mathrm{SE}( \pm)$ & - & - & - & - & - & 0.21 & - & - & - & - \\
\hline Sig. & NS & NS & NS & NS & NS & $*$ & NS & NS & NS & NS \\
\hline
\end{tabular}

In a column, the figure(s) having same letter are not significantly different by DMRT

*Significant at 5\% level, NS: Not significant

$5.2 \mathrm{~cm}$ in 2005-06) was observed in BARI Masur-2. Plant height increased over time in respective of varietal differences. In the beginning (up to 40 DAS), the rate of increase of plant height was sharp. Seeds collected from middle parts (P2) recorded significantly higher plant height at 20 DAS in 2004-05, and at 80 and 100 DAS in 2005-2006 (Table II). Plant height had higher values in P2 $(6.0 \mathrm{~cm}$ at 20 DAS, 23.4 $\mathrm{cm}$ at 60 DAS, $26.4 \mathrm{~cm}$ at 80 DAS in 2004-05 and $5.8 \mathrm{~cm}$ at 20 DAS, $15.3 \mathrm{~cm}$ at 40 DAS, $23.4 \mathrm{~cm}$ at 60 DAS, $30.0 \mathrm{~cm}$ at 80 DAS, $40.4 \mathrm{~cm}$ at 100 DAS in 2005-06) compared to $\mathrm{P}_{1}$ and $\mathrm{P}_{3}$ in almost all the sampling dates. This indicated that seeds collected from middle part of lentil plants $\left(\mathrm{P}_{2}\right)$ due to uptake of more nitrogen, caused a vigorous plant growth (Khatun et al., 2009). There was no significant interaction effect between varieties and seeds collected from different parts on plant height (Table III). The highest plant height of
(1993) reported that days to flowering were non-significant in different varieties of mungbean. Borate et al. (1993) observed that large size groundnut seed required 44 days for $50 \%$ flowering and small size seed required 42 days for $50 \%$ flowering. Fifty percent flowering ranged from 72 to 74 days over varieties and years (Table IV). It also ranged from 72 to 75 days over seeds collected from different parts and years (Table V). Non-significant interaction between varieties and harvesting of seed from different parts revealed that all the varieties performed similar results to seeds collection in the present study (Table VI).

\section{Days to maturity}

Days to maturity did not vary due to varieties and seeds collected from different parts, and also their interaction effect did not show significant variation (Tables IV-VI). Days to maturity ranged from 101 to 104 over varieties (Table IV) 
Table II. Effects of lentil seeds collected from different parts on plant height

\begin{tabular}{l|c|c|c|c|c|c|c|c|cc}
\hline \multirow{2}{*}{$\begin{array}{l}\text { Seeds } \\
\text { collected } \\
\begin{array}{c}\text { parts from } \\
\text { different }\end{array}\end{array}$} & \multicolumn{9}{|c}{$2004-05$} & \multicolumn{2}{c}{ Plant height $(\mathrm{cm})$} \\
\cline { 2 - 11 } & 20 DAS & 40 DAS & 60 DAS & 80 DAS & 100 DAS & 20 DAS & 40 DAS & 60 DAS & 80 DAS & 100 DAS \\
\hline $\mathrm{P}_{1}$ & $5.2 \mathrm{~b}$ & 14.1 & 23.2 & 25.6 & 35.3 & 5.4 & 14.1 & 22.1 & $28.0 \mathrm{~b}$ & $36.8 \mathrm{~b}$ \\
$\mathrm{P}_{2}$ & $6.0 \mathrm{a}$ & 14.0 & 23.4 & 26.4 & 36.2 & 5.8 & 15.3 & 23.4 & $30.0 \mathrm{a}$ & $40.4 \mathrm{a}$ \\
$\mathrm{P}_{3}$ & $5.8 \mathrm{a}$ & 14.6 & 22.6 & 25.7 & 36.4 & 5.7 & 14.1 & 22.3 & $29.2 \mathrm{ab}$ & $37.6 \mathrm{~b}$ \\
$\mathrm{SE}( \pm)$ & 0.181 & - & - & - & - & - & - & - & 0.48 & 0.61 \\
Sig. & $*$ & NS & NS & NS & NS & NS & NS & NS & $*$ & $* *$ \\
\hline
\end{tabular}

In a column, the figure(s) having same letter are not significantly different by DMRT

*Significant at 5\% level, **Significant at $1 \%$ level, NS: Not significant

P1: Seeds collected from upper part

P2: Seeds collected from middle part

P3: Seeds collected from lower part

Table III. Interaction effects of varieties and lentil seeds collected from different parts on plant

\begin{tabular}{|c|c|c|c|c|c|c|c|c|c|c|}
\hline \multirow{3}{*}{$\begin{array}{l}\text { Interaction } \\
\text { effects }\end{array}$} & \multicolumn{10}{|c|}{ Plant height $(\mathrm{cm})$} \\
\hline & \multicolumn{5}{|c|}{ 2004-05 } & \multicolumn{5}{|c|}{ 2005-06 } \\
\hline & 20 DAS & 40 DAS & 60 DAS & 80 DAS & 100 DAS & 20 DAS & 40 DAS & 60 DAS & 80 DAS & 100 DAS \\
\hline $\mathrm{V}_{1} \mathrm{P}_{1}$ & 5.0 & 13.3 & 22.7 & 27.3 & 34.0 & 5.1 & 12.9 & 19.5 & 25.8 & 36.1 \\
\hline $\mathrm{V}_{1} \mathrm{P}_{2}$ & 5.8 & 14.3 & 23.2 & 26.6 & 35.7 & 5.2 & 14.3 & 23.0 & 29.5 & 39.5 \\
\hline $\mathrm{V}_{1} \mathrm{P}_{3}$ & 5.5 & 13.9 & 23.1 & 22.9 & 36.3 & 5.2 & 14.8 & 21.6 & 29.4 & 36.6 \\
\hline $\mathrm{V}_{2} \mathrm{P}_{1}$ & 5.1 & 14.3 & 23.1 & 24.5 & 35.0 & 5.1 & 15.0 & 23.3 & 28.5 & 37.1 \\
\hline $\mathrm{V}_{2} \mathrm{P}_{2}$ & 6.0 & 13.3 & 23.4 & 26.1 & 36.7 & 6.4 & 15.9 & 22.7 & 29.5 & 40.6 \\
\hline $\mathrm{V}_{2} \mathrm{P}_{3}$ & 5.7 & 14.3 & 21.5 & 27.1 & 34.7 & 5.4 & 12.9 & 21.5 & 29.0 & 37.1 \\
\hline $\mathrm{V}_{3} \mathrm{P}_{1}$ & 5.6 & 14.8 & 23.8 & 24.9 & 37.0 & 5.9 & 14.6 & 23.6 & 29.7 & 37.2 \\
\hline $\mathrm{V}_{3} \mathrm{P}_{2}$ & 6.1 & 14.5 & 23.6 & 26.5 & 36.3 & 5.8 & 15.6 & 24.6 & 30.8 & 40.9 \\
\hline $\mathrm{V}_{3} \mathrm{P}_{3}$ & 6.3 & 15.5 & 23.2 & 27.2 & 38.3 & 6.4 & 14.4 & 23.8 & 29.3 & 39.1 \\
\hline $\mathrm{SE}( \pm)$ & - & - & - & - & - & - & - & - & - & - \\
\hline Sig. & NS & NS & NS & NS & NS & NS & NS & NS & NS & NS \\
\hline CV (\%) & 6.5 & 6.9 & 7.7 & 9.8 & 5.2 & 11.3 & 8.7 & 9.2 & 5.0 & 4.7 \\
\hline
\end{tabular}

NS: Not significant

$\mathrm{V}_{1} \mathrm{P}_{1}$ : BARI Masur-2 $\mathrm{x}$ Seeds collected from upper parts

$\mathrm{V}_{1} \mathrm{P}_{2}$ : BARI Masur- $2 \mathrm{x}$ Seeds collected seeds from middle parts

$\mathrm{V}_{1} \mathrm{P} 3$ : BARI Masur-2 $\mathrm{x}$ Seeds collected seeds from lower parts

$\mathrm{V}_{2} \mathrm{P}_{1}$ : BARI Masur- $3 \mathrm{x}$ Seeds collected seeds from upper parts

$\mathrm{V}_{2} \mathrm{P}_{2}$ : BARI Masur-3 $\mathrm{x}$ Seeds collected seeds from middle parts

$\mathrm{V}_{2} \mathrm{P}_{3}$ : BARI Masur- 3 x Seeds collected seeds from lower parts

$\mathrm{V}_{3} \mathrm{P}_{1}$ : BARI Masur- $4 \mathrm{x}$ Seeds collected seeds from upper parts

$\mathrm{V}_{3} \mathrm{P}_{2}$ : BARI Masur- $4 \mathrm{x}$ Seeds collected seeds from middle parts

$\mathrm{V}_{3} \mathrm{P}_{3}$ : BARI Masur- 4 x Seeds collected seeds from lower parts 
Table IV. Effects of varieties of lentil on days to flowering and maturity

\begin{tabular}{|c|c|c|c|c|c|c|}
\hline \multirow[t]{3}{*}{ Varieties } & \multicolumn{6}{|c|}{ Days to flowering and maturity } \\
\hline & \multicolumn{2}{|c|}{ 1st flowering } & \multicolumn{2}{|c|}{$50 \%$ flowering } & \multicolumn{2}{|c|}{ Maturity } \\
\hline & 2004-05 & 2005-06 & 2004-05 & 2005-06 & 2004-05 & 2005-06 \\
\hline BARI Masur-2 & 57 & 58 & 72 & 74 & 101 & 104 \\
\hline BARI Masur-3 & 57 & 58 & 73 & 73 & 102 & 104 \\
\hline BARI Masur-4 & 56 & 57 & 73 & 74 & 102 & 104 \\
\hline $\mathrm{SE}( \pm)$ & - & - & - & - & - & - \\
\hline Sig. & NS & NS & NS & NS & NS & NS \\
\hline
\end{tabular}

NS: Not significant

Table V. Effects of lentil seeds collected from different parts on days to flowering and maturity

\begin{tabular}{|c|c|c|c|c|c|c|}
\hline \multirow{3}{*}{$\begin{array}{l}\text { Seeds collected } \\
\text { from different parts }\end{array}$} & \multicolumn{6}{|c|}{ Days to flowering and maturity } \\
\hline & \multicolumn{2}{|c|}{ 1st flowering } & \multicolumn{2}{|c|}{$50 \%$ flowering } & \multicolumn{2}{|c|}{ Maturity } \\
\hline & 2004-05 & $2005-06$ & 2004-05 & $2005-06$ & 2004-05 & $2005-06$ \\
\hline $\mathrm{P}_{1}$ & 57 & 58 & 72 & 74 & 101 & 104 \\
\hline $\mathrm{P}_{2}$ & 56 & 57 & 73 & 74 & 102 & 104 \\
\hline $\mathrm{P}_{3}$ & 56 & 58 & 73 & 73 & 103 & 105 \\
\hline $\mathrm{SE}( \pm)$ & - & - & - & - & - & - \\
\hline Sig. & NS & NS & NS & NS & NS & NS \\
\hline
\end{tabular}

and years (Table V), and from 101 to 105 over seeds collected from different parts and years (Table VI).

\section{Pods plant ${ }^{-1}$}

Variety $\mathrm{x}$ seed collection effect on pod formation was not significant (Table IX). Varietals and effect of seed collection was also not significant in any of the years (Tables VII and VIII). Pods plant ${ }^{-1}$ (mean of seed collection) was the highest in BARI Masur-4, while the lowest in BARI Masur-2. Tomar et al. (2000) reported that among four varieties of lentil genotype Pant L 639 recorded significantly higher pods plant $^{-1}$. Seeds collected from middle part $\left(\mathrm{P}_{2}\right)$ of lentil crops (average of three varieties) produced higher pods plant ${ }^{-1}$. This might be due to higher germination and higher vigour index. Borate et al. (1993) observed that pods plant ${ }^{-1}$ was higher (19.2) in large size seeds and lower (12.9) in small size seed of groundnut. Singh and Verma (1999) reported that number of pods plant ${ }^{-1}$ varied significantly in lentil. The highest pods plant- 1 (76.0) was noted in $\mathrm{V}_{2} \times \mathrm{P}_{3}$ in 2004-05 and 75.1 were noted in $\mathrm{V}_{3} \times \mathrm{P}_{3}$ in 2005-06 (Table IX).

\section{Seeds pod ${ }^{-1}$}

Varieties had a significant effect for seeds pod ${ }^{-1}$ in 20052006 and of seed collection was also found to be significant while the interaction effect was not significant (Tables VIIIX). BARI Masur-4 produced the highest number of seeds $\operatorname{pod}^{-1}$ (1.74 in 2004-05 and 1.71 in 2005-06), which was statistically similar to BARI Masur-3 in 2005-06 (Table VII). The same variety also yielded the highest seeds $\operatorname{pod}^{-1}$ in 2004-05 but identical to other two varieties. Bhingarde and Dumbre (1993) reported that large sized seed gave higher number of seeds $\operatorname{pod}^{-1}$ (8.1 seed) and smaller size seed gave lower seeds $\operatorname{pod}^{-1}$ (7.5 seed) in mungbean. Tomar et al. (2000) and Singh and Verma (1999) reported that number of grains $\operatorname{pod}^{-1}$ varied significantly in lentil. In the present study, large sized seed (BARI Masur-4) produced higher seeds $\operatorname{pod}^{-1}$. The present results corroborated with the above findings. Seeds collected from middle parts of lentil (P2) significantly increased number of seeds pod ${ }^{-1}$ (Table VIII). The highest seeds $\operatorname{pod}^{-1}$ (1.79 in 2004-05 and 1.70 in 200506)was found in P2 which was identical to P3. Seeds collected from upper parts recorded the lowest seeds $\operatorname{pod}^{-1}$. Interaction effect of variety and seeds collected from different parts regarding number of seeds pod $^{-1}$ was not statistically significant (Table IX). Higher number of seeds pod $^{-1}$ was observed in $\mathrm{V}_{3} \times \mathrm{P}_{2}$.

\section{0-seed weight}

Varieties had no significant effect on 1000-seed weight (Table VII). Different parts for 1000-seed weight were found to be significant, and their interaction effect variety and parts was significant only in 2005-06 (Tables VIII and IX). 
Table VI. Interaction effects of lentil varieties and seeds collected from different parts on days to flowering and maturity

\begin{tabular}{|c|c|c|c|c|c|c|}
\hline \multirow[t]{3}{*}{ Interactioneffects } & \multicolumn{6}{|c|}{ Days to flowering and maturity } \\
\hline & \multicolumn{2}{|c|}{ 1st flowering } & \multicolumn{2}{|c|}{$50 \%$ flowering } & \multicolumn{2}{|c|}{ Maturity } \\
\hline & 2004-05 & 2005-06 & 2004-05 & $2005-06$ & 2004-05 & 2005-06 \\
\hline $\mathrm{V}_{1} \mathrm{P}_{1}$ & 58 & 58 & 72 & 73 & 101 & 104 \\
\hline $\mathrm{V}_{1} \mathrm{P}_{2}$ & 57 & 58 & 73 & 73 & 101 & 103 \\
\hline $\mathrm{V}_{1} \mathrm{P}_{3}$ & 56 & 58 & 72 & 75 & 102 & 105 \\
\hline $\mathrm{V}_{2} \mathrm{P}_{1}$ & 57 & 58 & 72 & 74 & 101 & 104 \\
\hline $\mathrm{V}_{2} \mathrm{P}_{2}$ & 55 & 57 & 72 & 73 & 103 & 104 \\
\hline $\mathrm{V}_{2} \mathrm{P}_{3}$ & 58 & 58 & 73 & 73 & 102 & 104 \\
\hline $\mathrm{V}_{3} \mathrm{P}_{1}$ & 57 & 57 & 72 & 74 & 101 & 104 \\
\hline $\mathrm{V}_{3} \mathrm{P}_{2}$ & 55 & 55 & 73 & 75 & 102 & 104 \\
\hline $\mathrm{V}_{3} \mathrm{P}_{3}$ & 55 & 59 & 75 & 73 & 104 & 105 \\
\hline $\operatorname{SE}( \pm)$ & - & - & - & - & - & - \\
\hline Sig. & NS & NS & NS & NS & NS & NS \\
\hline CV (\%) & 5.0 & 3.7 & 2.6 & 1.7 & 2.6 & 0.8 \\
\hline
\end{tabular}

NS: Not significant

Maximum weight of 1000-seeds (19.3 g in 2004-05 and 20.1 $\mathrm{g}$ in 2005-06) was obtained in BARI Masur-3 (mean of harvesting parts). Bhingarde and Dumbre (1993) reported that large sized seed gave higher 100-seed weight (3.49 g) and smaller size seed gave lower 100-seed weight (3.09 g) in mungbean. Tomar et al. (2000) reported that among four varieties of lentil genotype Pant L 639 recorded significantly higher 1000-seed weight. Borate et al. (1993) observed that 1000-seed weight was higher (235 g) in large size seeds and lower (197 g) in small size seed of groundnut. Singh and Verma (1999) reported that 1000-seed weight of lentil varied significantly. They reported that 1000 -seed weight was always higher in bold seeded lentil. The present results corroborated somewhat with the findings by Singh and Verma (1999). Seeds collected from different parts significantly increased 1000-seed weight (Table VIII). Results showed that 1000-seed weight (mean of variety) was higher (20.2 g in 2004-05 and 21.3 g in 2005-06) when seeds were collected from middle parts $\left(\mathrm{P}_{2}\right)$ or lower parts $\left(\mathrm{P}_{3}\right)$. Interaction effects of variety $\mathrm{x}$ seeds collected from different parts was significant only in 2005-06 (Table IX). The highest 1000seed weight was recorded in $\mathrm{V}_{2} \times \mathrm{P}_{3}$ in 2004-05 and $\mathrm{V}_{2} \times \mathrm{P}_{2}$ in 2005-06.

\section{Seed yield}

Three lentil varieties varied significantly in terms of seed yield in 2004-05 (Table VII). The highest seed yield of 856 $\mathrm{kg} \mathrm{ha}^{-1}$ was recorded in BARI Masur-4 in 2004-05 that was statistically similar to BARI Masur-3 but dissimilar to BARI Masur-2. BARI Masur-4 produced higher pods plant ${ }^{-1}$ andseeds pod $^{-1}$, which resulted in higher seed yield. BARI Masur-4 also recorded higher seed yield $\left(847 \mathrm{~kg} \mathrm{ha}^{-1}\right)$ in 2005-06, which was identical to other two varieties. BARI Masur-3 recorded the second highest seed yield (734 $\mathrm{kg} \mathrm{ha}^{-1}$ in 2004-05 and $786 \mathrm{~kg} \mathrm{ha}^{-1}$ in 2005-06), which was fol-

Table VII. Effects of varieties of lentil on yield and yield attribute

\begin{tabular}{|c|c|c|c|c|c|c|c|c|}
\hline \multirow[t]{2}{*}{ Variety } & \multicolumn{2}{|c|}{$\begin{array}{l}\text { Number of pods } \\
\text { plant }^{-1}\end{array}$} & \multicolumn{2}{|c|}{$\begin{array}{l}\text { Number of seeds } \\
\text { pod }^{-1}\end{array}$} & \multicolumn{2}{|c|}{$\begin{array}{l}\text { 1000-seed weight } \\
\text { (g) }\end{array}$} & \multicolumn{2}{|c|}{$\begin{array}{c}\text { Seed } \\
\text { yield }\left(\mathrm{kg} \mathrm{ha}^{-1}\right)\end{array}$} \\
\hline & 2004-05 & 2005-06 & 2004-05 & 2005-06 & 2004-05 & 2005-06 & 2004-05 & 2005-06 \\
\hline BARI Masur-2 & 67.7 & 67.5 & 1.62 & $1.57 \mathrm{~b}$ & 18.6 & 18.6 & $714 \mathrm{~b}$ & 719 \\
\hline BARI Masur-3 & 70.6 & 70.4 & 1.70 & $1.61 \mathrm{ab}$ & 19.3 & 20.1 & 734ab & 786 \\
\hline BARI Masur-4 & 71.4 & 71.2 & 1.74 & $1.71 \mathrm{a}$ & 18.8 & 19.3 & $856 a$ & 847 \\
\hline $\mathrm{SE}( \pm)$ & - & - & - & 0.032 & - & - & 30.82 & - \\
\hline Sig & NS & NS & NS & $*$ & NS & NS & $* *$ & NS \\
\hline
\end{tabular}

In a column, the figure(s) having same letter are not significantly different by DMRT

*Significant at 5\% level, **Significant at 1\% level, NS: Not significant 
lowed by BARI Masur-2. BARI Masur-2 gave the minimum yield (714 kg ha ${ }^{-1}$ in 2004-05 and $719 \mathrm{~kg} \mathrm{ha}^{-1}$ in 2005-06). The present result is in agreement with Afzal et al. (2003), who reported that varieties of lentil differed significantly in seed yield. Afzal et al. (1999) also observed that BARI Masur-4 gave the highest seed yield. The fresh weight of seed showed significant variations due to varieties (Jayaraj and Karivaratharaju, 1992). They reported that among different varieties, the highest (285 mg) and the lowest (219 mg) mean fresh weight of groundnut were noticed in JL 24 and TMV 12, respectively. Bhingarde and Dumbre (1993) reported that large sized seed gave higher seed yield (858 kg $\mathrm{ha}^{-1}$ ) and smaller size seed gave lower seed yield (763 kg $\mathrm{ha}^{-1}$ ) in mungbean. Borate et al. (1993) observed that seed yield was higher $\left(1.46 \mathrm{t} \mathrm{ha}^{-1}\right)$ in large size seeds and lower (0.99 $\left.\mathrm{t} \mathrm{ha}^{-1}\right)$ in small size seed of groundnut. Singh and
Verma (1999) reported that seed yield of lentil varied significantly. Seeds collected from different parts did not significantly increase the seed yield of lentil (Table VIII), though the increase in yield due to seeds collected from middle parts compared to upper part was $12.0 \%$ in $2004-05$ and $14.3 \%$ in 2005-06. The increase in yield in middle part of lentil crop might be increased seeds pod-1 and pods plant-1. Interaction effects of different varieties and seeds of different parts were significant in seed yield (Table IX). In 2004-05, BARI Masur-4 gave the highest yield when most pods were lightbrown with a few yellow green $\left(\mathrm{V}_{3} \mathrm{x} \mathrm{P}_{2}\right)$ compared to other treatments combinations but identical to $\mathrm{V}_{1} \times \mathrm{P}_{1}$ and $\mathrm{V}_{2} \times \mathrm{P}_{2}$ in 2004-05. But in 2005-06, the treatment combination of $\mathrm{V}_{2}$ $\mathrm{x} \mathrm{H}_{2}$ gave the highest yields but identical to $\mathrm{V} 1 \times \mathrm{P}_{3}, \mathrm{~V}_{3} \times \mathrm{P}_{1}$, $\mathrm{V}_{3} \times \mathrm{P}_{2}$ and $\mathrm{V}_{3} \times \mathrm{P}_{3}$.

Table VIII. Effects of lentil seeds collected from different parts on yield and yield attributes

\begin{tabular}{l|c|c|c|c|c|c|c|c}
\hline \multirow{2}{*}{$\begin{array}{l}\text { Seeds } \\
\text { collected from }\end{array}$} & \multicolumn{2}{|c|}{$\begin{array}{c}\text { Number of pods } \\
\text { plant }^{-1}\end{array}$} & \multicolumn{2}{c|}{$\begin{array}{c}\text { Number of seeds } \\
\text { pod }^{-1}\end{array}$} & \multicolumn{2}{c|}{$\begin{array}{c}\text { 1000-seed weight } \\
\text { (g) }\end{array}$} & \multicolumn{2}{c}{$\begin{array}{c}\text { Seed } \\
\text { yield(kg ha }{ }^{-1} \text { ) }\end{array}$} \\
\cline { 2 - 9 } different parts & $2004-05$ & $2005-06$ & $2004-05$ & $2005-06$ & $2004-05$ & $2005-06$ & $2004-05$ & $2005-06$ \\
\hline $\mathrm{P}^{1}$ & 66.8 & 68.3 & $1.59 \mathrm{~b}$ & $1.54 \mathrm{~b}$ & $17.4 \mathrm{~b}$ & $17.0 \mathrm{~b}$ & 718 & 733 \\
$\mathrm{P}^{2}$ & 71.9 & 71.2 & $1.79 \mathrm{a}$ & $1.70 \mathrm{a}$ & $19.1 \mathrm{ab}$ & $21.3 \mathrm{a}$ & 804 & 838 \\
$\mathrm{P}^{3}$ & 71.0 & 69.6 & $1.69 \mathrm{ab}$ & $1.64 \mathrm{ab}$ & $20.2 \mathrm{a}$ & $19.7 \mathrm{a}$ & 781 & 782 \\
$\mathrm{SE}( \pm)$ & - & - & 0.030 & 0.032 & 0.59 & 0.49 & - & - \\
Sig. & NS & NS & $*$ & $*$ & $*$ & $* *$ & NS & NS \\
\hline
\end{tabular}

In a column, the figure(s) having same letter are not significantly different by DMRT

*Significant at 5\% level, **Significant at $1 \%$ level, NS: Not significant

Table IX. Interaction effects of lentil varieties and seeds collected from different parts on yield and yield attributes

\begin{tabular}{l|c|c|c|c|c|c|c|c}
\hline \multirow{2}{*}{$\begin{array}{l}\text { Seeds } \\
\text { collected from } \\
\text { different parts }\end{array}$} & \multicolumn{2}{|c|}{$\begin{array}{c}\text { Number of pods } \\
\text { plant }^{-1}\end{array}$} & \multicolumn{2}{c|}{$\begin{array}{c}\text { Number of seeds } \\
\text { pod }^{-1}\end{array}$} & \multicolumn{2}{c|}{$\begin{array}{c}\text { 1000-seed weight } \\
\text { (g) }\end{array}$} & \multicolumn{2}{c}{$\begin{array}{c}\text { Seed } \\
\text { yield(kg ha-1 }\end{array}$} \\
\cline { 2 - 9 } & $2004-05$ & $2005-06$ & $2004-05$ & $2005-06$ & $2004-05$ & $2005-06$ & $2004-05$ & $2005-06$ \\
\hline $\mathrm{V}_{1} \mathrm{P}_{1}$ & 69.0 & 69.9 & 1.47 & 1.47 & 18.3 & $18.8 \mathrm{bc}$ & $846 \mathrm{ab}$ & $714 \mathrm{~b}$ \\
$\mathrm{~V}_{1} \mathrm{P}_{2}$ & 69.3 & 71.7 & 1.70 & 1.70 & 17.5 & $19.5 \mathrm{abc}$ & $614 \mathrm{c}$ & $658 \mathrm{~b}$ \\
$\mathrm{~V}_{1} \mathrm{P} 3$ & 64.7 & 61.0 & 1.70 & 1.53 & 19.9 & $17.6 \mathrm{~cd}$ & $681 \mathrm{c}$ & $786 \mathrm{ab}$ \\
$\mathrm{V}_{2} \mathrm{P}_{1}$ & 62.7 & 65.7 & 1.53 & 1.60 & 17.9 & $17.6 \mathrm{~cd}$ & $595 \mathrm{c}$ & $644 \mathrm{~b}$ \\
$\mathrm{~V}_{2} \mathrm{P}_{2}$ & 73.0 & 72.6 & 1.77 & 1.60 & 18.6 & $23.4 \mathrm{a}$ & $1003 \mathrm{ab}$ & $1012 \mathrm{a}$ \\
$\mathrm{V}_{2} \mathrm{P}_{3}$ & 76.0 & 72.8 & 1.80 & 1.63 & 21.4 & $19.4 \mathrm{abc}$ & $603 \mathrm{c}$ & $704 \mathrm{~b}$ \\
$\mathrm{~V}_{3} \mathrm{P}_{1}$ & 68.7 & 69.3 & 1.77 & 1.57 & 15.9 & $14.5 \mathrm{~d}$ & $714 \mathrm{c}$ & $841 \mathrm{ab}$ \\
$\mathrm{V}_{3} \mathrm{P}_{2}$ & 73.3 & 69.2 & 1.90 & 1.80 & 21.2 & $21.1 \mathrm{abc}$ & $794 \mathrm{bc}$ & $846 \mathrm{ab}$ \\
$\mathrm{V}_{3} \mathrm{P}_{3}$ & 72.3 & 75.1 & 1.57 & 1.77 & 19.2 & $22.2 \mathrm{ab}$ & $1061 \mathrm{a}$ & $856 \mathrm{ab}$ \\
$\mathrm{SE}( \pm)$ & - & - & - & - & - & 0.84 & 53.34 & 70.52 \\
$\mathrm{Sig}$. & $\mathrm{NS}$ & $\mathrm{NS}$ & $\mathrm{NS}$ & $\mathrm{NS}$ & $\mathrm{NS}$ & $* *$ & $* *$ & $*$ \\
$\mathrm{CV}(\%)$ & 8.1 & 10.0 & 8.1 & 5.9 & 9.4 & 7.5 & 12.0 & 15.6 \\
\hline
\end{tabular}

In a column, the figure(s) having same letter are not significantly different by DMRT

*Significant at 5\% level, **Significant at $1 \%$ level, NS: Not significant 


\section{Conclusion}

The overall results revealed that the highest plant height, pods plant ${ }^{-1}$, seeds pod $^{-1}, 1000$-seed weight and seed yield was observed in BARI Masur-4 and the lowest in BARI Masur-2. Seeds collected from different parts had no effect on different parameters studied except plant height at 20 DAS in 2004-05, and 80 and 100 DAS in 2005-06, seeds pod ${ }^{-1}$ and 1000-seed weight both in 2004-05 and 2005-06. Seeds collected from middle part of lentil $\left(\mathrm{P}_{2}\right)$ recorded the highest pods plant $^{-1}$, seeds pod ${ }^{-1}, 1000$-seed weight and seed yield.

\section{References}

Abdul-Baki A. A. and Baker J.E. (1973) Are changes in cellular organelles or membranes related to vigour loss in seeds. Seed Sci. Technol. 1: 89-125.

Afzal M. A., Bakr M. A. and Rahman M. L. (1999) Lentil Cultivation in Bangladesh. Lentil, Blackgram and Mungbean Development Pilot Project, Pulses Research Station, BARI, Gazipur-1701. Publication No. 18. p. 64.

Afzal M. A., Bakr M. A., Hamid A., Haque M. M. and Aktar, M.S. (2003) Lentil in Bangladesh. Lentil, Blackgram and Mungbean Development Pilot Project, Pulses Research Station, BARI, Gazipur-1701. Publication No. 24. pp. 27-31.

Baburatan P., Eswarareddy S. and Narayanareddy Y. (1993) Influence of water soaking of Annona (Annona squamosa L.) seed on germination and subsequent seedling growth. South Indian Hort. 41: 171-173.

Bhingarde M. T. and Dumbre A. D. (1993) Effect of seed size on growth and yield components in greengram (Vigna radiata L. Wilczek) under summer conditions. Seed Res. 21(2): 104-106.

BBS. (2006) Statistical Yearbook of Bangladesh. 21th Edition. Bangladesh Bureau of Statistics. Ministry of Planning, Govt. People's Republic of Bangladesh. p. 143.

Borate D. N., Dumbre A. D. and Bhingarde M. T. (1993) Effect of seed size on growth, yield and seed quality of groundnut (Arachis hypogaea L.) under summer conditions. Seed Res. 21(2): 107-109.

Delouche J. C. (1973) Seed marturation. Seed Production Mannual NSC and Rockfeller Foundation. pp. 162-165.

Dharmalingam C. Basu R. N. (1990) Seed development and maturation in mungbean. Seed Res. 18(1): 1-6.

Dharmalingam C. and Ramakrishnan V. (1978) Seed quality in relation to seed size and seed coat colour variation in blackgram (Vigna radiata (L.) Hepper). Seed Res. 6: 101-109.

Harrington J. F. (1972) Seed storage and longevity. In: Seed Biology, VII. (T.T. Kozlowski, ed.). Academic Press, New York. pp. 145-245.

Jayaraj T. and Karivaratharaju T. V. (1992) Influnce of harvesting stage on seed vigour in groundnut cultivar. Seed Res. 20(1): 41-43.

Khare D. and Satpute R.G. (1999) Influence of days to maturity and seed size on germination and seedling vigour in pigeonpea. Seed Res. 27(2): 170-173.

Khatun A., Bhuiyan M. A. H. and Ayub A. (2008) Storability of lentil (Lens culinaris L.) seed as influenced by seed collection. Bull. Inst. Trop. Agr., Kyushu Univ. 31: 1-8.

Khatun A., Bhuiyan M. A. H. and Dey T. K. (2009) Nitrogen uptake and protein yield in lentil as affected by seed collection from different parts of plants. Bangladesh $\mathrm{J}$. Agril. Res. Vol. 34.

Kumar V., Shahidhan S. D., Kurdikeri M. B., Channaveeraswami A. S. and Hosmani R. M. (2002) Influence of harvesting stages on seed yield and quality in paprika (Capsicum annuum L.). Seed Res. 30(1): 99-103.

Mehta C. J., Kuhad M. S., Sheoran I. S. and Nandwal A.S. (1993) Studies on seed development and germination in chickpea cultivars. Seed Res. 21(2): 89-91.

Ovcharov K. K. and Kizilova K.G. (1966) Differences in seed quality and plant productivity. In: Physiological Basisof Seed Germination. Amerind Publishing, New Delhi. pp. 54-140.

Ponnuswamy R. L., Miller R.H. and Luckmann W.H. (1991) Introduction to Insect Pest Management. John Wiley and Sons. New York. pp. 235-273.

Reddy Y. T. N. and Khan M.M. (2001) Effect of osmopriming on germination, seedling growth and vigour of khirni (Mimusops hexandra) seeds. Seed Res. 29(1): 24-27.

Singh R. M. and Verma R. S. (1999) Effect of seeding rate and row spacing on the yield and quality of lentil (Lens culinaris) varieties. Indian J. Agron. 44(3): 584-587.

Tomar S. K., Tripathi P. and Rajput A. L. (2000) Effect of genotype, seeding method and diammonium phosphate on yield and protein and nutrient uptake by lentil (Lens culinaris). Indian J. Agron. 45(1): 148-152.

Received : July 05, 2009;

Accepted : January 06, 2010 